\title{
Retinofugal Projections in the Lepidosirenid Lungfishes
}

\author{
R. GLENN NORTHCUTT \\ Division of Biological Sciences, University of Michigan, Ann Arbor, Michigan 48109
}

\begin{abstract}
Autoradiographic and silver methods indicate that the African and South American lungfishes, Protopterus and Lepidosiren, lack ipsilateral retinal projections. Contralaterally, the retina projects to the preoptic nucleus of the hypothalamus, to four discrete areas located in the lateral neuropil of the thalamus, to a superficial pretectal neuropil, to the upper half of the tectal neuropil, and to a laterally situated basal optic neuropil located in the rostral teg. mentum. The overall pattern of the primary retinofugal projections is markedly similar to that of amphibians which suggests that lungfishes may be more closely related to amphibians than to actinopterygian fishes. Neotenic trends in both lepidosirenid lungfishes and urodeles may be expressions of parallelism, hence Latimeria and Neoceratodus must be examined to resolve this phylogenetic problem. A 300-fold range in the size of the eye, indicated by the number of ganglion cells present, occurs among lungfishes, salamanders and frogs. This variation may have implications for recognizing the morphological expression of selection operating on the visual systems of lepidosirenids and amphibians.
\end{abstract}

The lungfishes or dipnoans are most frequently recognized as a subclass or infraclass (Dipnoi) of the bony fishes (Osteichthyes). At present, six species of lungfishes are relegated to two families: Lepidosirenidae and Ceratodontidae. The lepidosirenids consist of the African genus Protopterus with four recognized species and the monotypic South American genus Lepidosiren. The Ceratodontidae includes only the single Australian species Neoceratodus fosteri, considered the most primitive living lungfish (Moy-Thomas, '71).

The taxonomic relationship of lungfishes to other fishes is presently in dispute. Romer (66) divided the bony fishes into two clades or subclasses, the actinopterygians and the sarcopterygians. He believed the lungfishes should be grouped with the sarcopterygians and thus interpreted the lungfishes as being more closely related to the crossopterygians than to other living fishes. If Romer was correct, the lungfishes and crossopterygians are the only surviving fishes that are closely re lated to those that gave rise to land vertebrates.

Dipnoans have also been suggested to be more closely related to actinopterygians (Bertmar, '68a,b), or to chondrichthyans (Jarvik, '67, '68) or again as forming a distinct and equally old radiation within the bony fishes (Schaeffer, '68). Most of these phylogenetic arguments have relied on hard structures such as the presence or absence of cosmine layers on the dermal bones and scales, and upon such characteristics as tail shape, number of dorsal fins, the course of the lateral line organs on the head, and the pattern of skull roofing bones.

The phyletic relationship of dipnoans to other osteichthyans is an unsolved problem because many of the taxonomic characters that have been used are primitive gnathostome characters shared by chondrichthyans, or superficial similarities that may have arisen independently a number of times due to early vertebrate radiations possessing similar genomes and invading similar ecological zones. This type of morphological similarity is termed parallelism (Simpson, '61; Mayr, '69) and is one of the major interpretational problems encountered in phyletic analyses of closely related taxa.

Sufficient experimental data on the retinofugal projections of actinopterygians and land vertebrates is presently available to contrast these two groups. The major features of the primary retinofugal projections of land vertebrates have been reviewed by Riss and Jak- 
way ('70) and Ebbesson ('70). Similar studies on the primary retinofugal projections in actinopterygians have been summarized by Northcutt and Butler ('76). Experimental studies on actinopterygian retinal projections have revealed a deep or medial optic pathway that runs just lateral to the periventricular gray of the diencephalon and, at the level of the posterior commissure, bifurcates to terminate in the pretectum as well as the deeper layers of the optic tectum. While all studies have not reported a basal or tegmental optic tract in actinopterygians, those that have reported such a pathway describe it as arising from the ventral optic tract and coursing medially into a nuclear group located just lateral to the periventricular gray of the tegmentum. In all land vertebrates the basal optic tract runs just beneath the pial surface of the tegmentum, and the basal optic nucleus is a migrated cell group embedded in the optic tract fibers lying just lateral to the exit of the oculomotor nerve (Butler and Northcutt, '71).

While the analysis of one set of characters under common selective pressure(s), as are the primary retinofugal pathways, cannot resolve the relationship between dipnoans and other fishes, each additional set of characters serves to clarify this relationship. This study reports on the first of a series of experiments in progress on the central nervous system of dipnoans.

An analysis of the visual system of lepidosirenid lungfishes may also yield information on the possible loss of retinal targets associated with neoteny. Ali and Anctil ('73) reported that Lepidosiren has one of the highest ratios of photoreceptors to retinal ganglion cells $(2: 1)$ of any vertebrate. The lepidosirenid retina contains only 1,500 ganglion cells and the sparseness and large size of the retinal cells suggests that the retina has stopped developing during its growth. Similar results regarding the retinal organization of lungfishes were reported by Rochon-Duvigneaud ('41, 43). Similarly the brains of lepidosirenid lungfishes possess a number of larval-like features (fig. 1). The optic tectum does not evaginate to form marked lateral recesses, and almost all the cell bodies of the neurons of the diencephalon and mesencephalon are located in a periventricular position.

These neotenic features of the nervous system of lepidosirenid lungfishes are most comparable to those of urodele amphibians. The brains of anuran amphibians are distinctly different. Anurans possess well developed diencephalic nuclei and tectal cellular laminae and are heavily dependent on vision in mediating much of their behavior.

Comparisons of the number of retinal targets among lepidosirenid lungfishes, urodeles and anuran amphibians allows us to test whether failure of neurons to migrate from the embryonic matrix zone, which produces a more simple cytological brain region, also results in fewer distinet retinal targets.

\section{MATERIALS AND METHODS}

Seven specimens of Protopterus annectens (Owen, 1839) and two specimens of Lepidosiren paradoxa (Fitzinger, 1836) sustained unilateral enucleation under MS-222 (tricaine) anesthesia. Experimental animals included both juveniles and adults. After survival times of 7 to 47 days at $30^{\circ} \mathrm{C}$, the animals were sacrificed by transcardial perfusion with $0.7 \%$ saline followed by $10 \%$ formalin.

Abbreviations

a, acoustico-lateral area an, anterior lateral line nerve bot, basal optic tract c, cerebellar plate dh, dorsal hypothalamus $\mathrm{dt}$, dorsal thalamus dtn, dorsal thalamic neuropil $\mathrm{f}$, fasciculus retrofiexus h, habenula

hc, habenular commissure it, isthmal tegmentum Ifb, lateral forebrain bundle mt, mesencephalic tegmentum $\mathrm{nb}$, neuropil of Bellonci $\mathrm{ni}$, nucleus interstitialis

\author{
np, nucleus periventricularis preopticus \\ ob, olfactory bulb \\ oc, optic chiasma \\ ocn, occipital nerve \\ on, optic nerve \\ ot, optic tract \\ ote, optic tectum \\ pc, posterior commissure \\ pcp, pretectal cell plate \\ pln, posterior lateral line nerve \\ pn, pretectal neuropil \\ s, stria medullaris \\ sc, subcommissural organ \\ sh, superior hypothalamic sulcus \\ sin, superficial isthmal nucleus
}

\author{
sm, sulcus medius \\ ss, sulcus subhabenularis \\ tel, telencephalon \\ tn, tectal neuropil \\ $t 1$, terminal fields in thalamus \\ $\mathrm{t} 2$, terminal fields in thalamus \\ $\mathbf{t} 3$, terminal fields in thalamus \\ $t 4$, terminal fields in thalamus \\ vh, ventral hypothalamus \\ vt, ventral thalamus \\ $v t n$, ventral thalamic neuropil \\ $\mathrm{V}$, trigemino-facial complex \\ VIII, acoustico-vestibular nerve \\ IX, glossopharyngeal nerve \\ $\mathrm{X}$, vagal complex
}




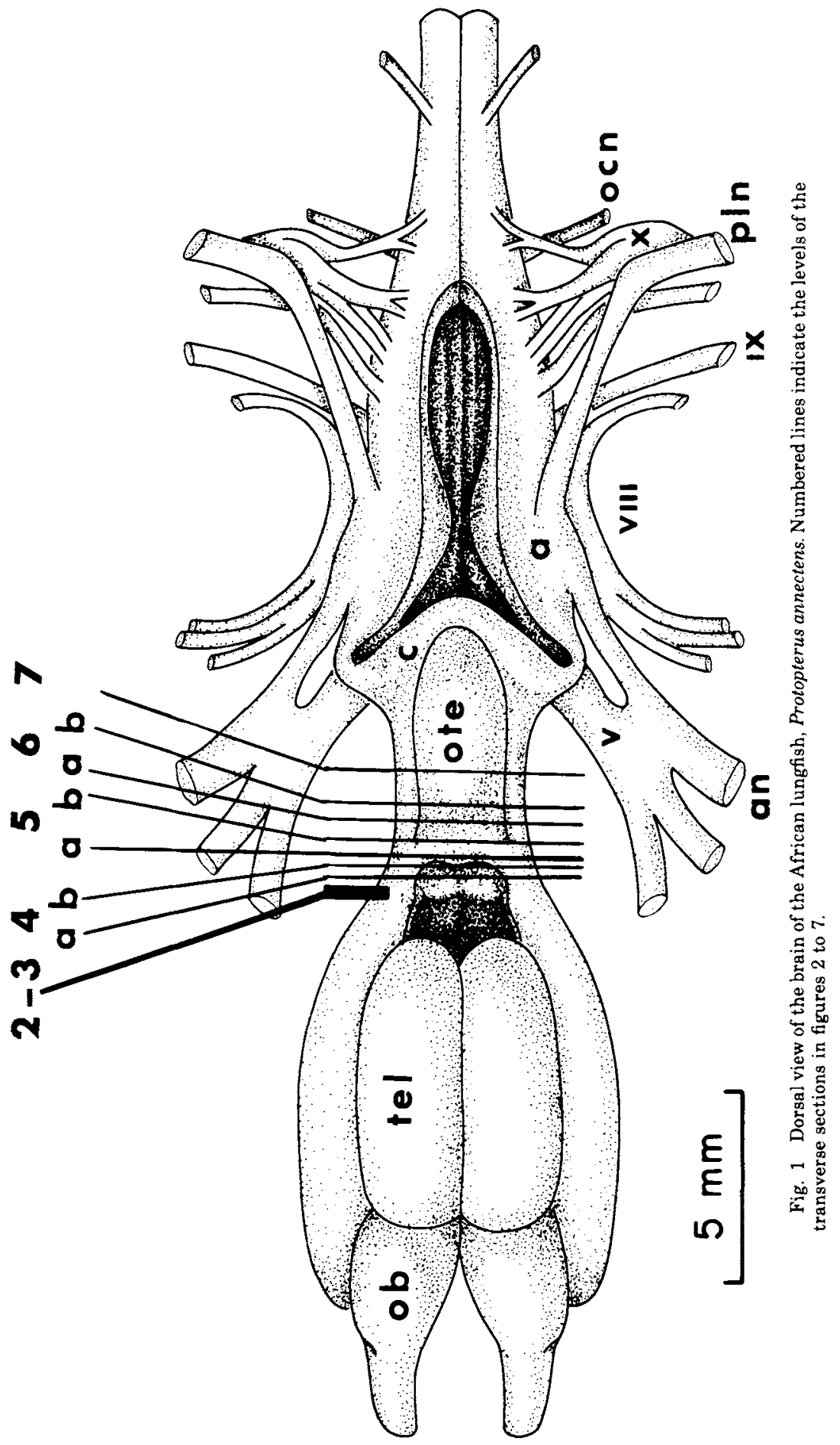


After further fixation for at least seven days in $10 \%$ formalin, the brains were embedded in $25 \%$ gelatin. Frozen sections were cut at $25 \mu$ and stored in $2 \%$ formalin in a refrigerator, and processed by several modifications of the Fink-Heimer I procedure (Fink and Heimer, '67) for the demonstration of degenerating axoplasm.

An additional specimen of Protopterus was processed for autoradiography following intraocular injection of $20 \mu \mathrm{C}$ of $\mathrm{L}-\left(4,5-{ }^{3} \mathrm{H}\right)$ proline, $20 \mu \mathrm{C} / \mu \mathrm{l}$, with a $5 \mu \mathrm{l}$ Hamilton syringe and 26 gauge needle. The animal was allowed to survive 72 hours postoperatively, at which time it was perfused with AFA $(90 \mathrm{cc}$ of $80 \%$ ethanol, $5 \mathrm{cc}$ formalin, and $5 \mathrm{cc}$ glacial acetic acid). The injected eye and the brain were removed and stored in AFA for one week prior to dehydration and embedding in paraffin. Both the eye and brain were cut in the transverse plane at $15 \mu$. Kodak NTB3 nuclear track emulsion was diluted $1: 1$ with distilled water at $40^{\circ} \mathrm{C}$, and the slides were dipped into the emulsion and dried for approximately one hour. The sections were exposed for 20 days and developed in Kodak Dektol and stained with cresyl violet. Selected sections from this autoradiographic case were photographed on Kodalith Ortho film, type 3, with a Leitz large-format camera. The distribution of the retinofugal pathways and their terminal fields were charted on these photographs, which were then compared with the anterograde degeneration cases, and with non-experimental Bodian stained material as an aid in separating terminal fields from fibers of passage.

Additional series of sections (cut in the three standard anatomical planes) from both species were processed with Bodian and Nissl methods for study of nuclear groups and fiber tracts.

\section{RESULTS}

Following unilateral enucleation, survival times of 7 to 25 days revealed silver impregnation of terminal fields. Survival times longer than 25 days revealed degenerating axons of passage but little in the way of terminal fields. Axonal debris was still present in the optic pathways in the longest survival times of 47 days. As in amphibians (Jakway and Riss, '72; Kokoros and Northcutt, '77) two types of degenerating products stained in the silver preparations. Fine punctate granules were seen at shorter survival times and were interpreted as degenerating preterminals and terminals. Larger varicose rods, prominent in the optic tract (fig. 8A), were still present at longer survival times and were interpreted as degenerating axons.

With few exceptions most of the degenerating debris was confined to the neuropil and probably represents axo-dendritic or axoaxonic terminations. The interpretation of these neuropil targets is complicated by the observation that many of the retinal targets lie lateral to more than a single cytological division of the periventricular gray. Thus it is probable that dendrites of cells in several periventricular "nuclei" extend into the path of the degenerating optic fibers. Further resolution of the retinal terminations, particularly in the thalamus, will require Golgi and electron microscopic studies.

Terminal fields, as determined with the autoradiographic method, were recognized by an increase in grain density, particularly when high density fields were located outside the major divisions of the optic tract (fig. 8B) as indicated by Bodian preparations or by phase contrast of the autoradiographic sections. These criteria were not applicable for the basal optic tract, and the extent of a terminal field(s) could not be ascertained.

Both methods showed similar courses and terminations of retinal projections, although the autoradiographic technique provided more details of the extent of the thalamic projections than did the silver methods. Figure 1 shows the levels of the illustrated sections charting the primary retinofugal pathways (figs. 2-7).

The brains of Protopterus and Lepidosiren are almost identical, suggesting, as have many non-neural studies, that these taxa are very closely related. The similarities are so great, in fact, that there is little reason to assign these taxa to separate genera.

The experimentally determined retinofugal projections do not differ significantly between these two species. The following descriptions are based on $P$. annectens, but also apply to $L$. paradoxa unless specified otherwise.

\section{Normal anatomy}

While a number of studies exist on the organization of the dipnoan telencephalon (see Nieuwenhuys and Hickey, '65; Schnitzlein and Crosby, '67; Clairambault and Capanna, 

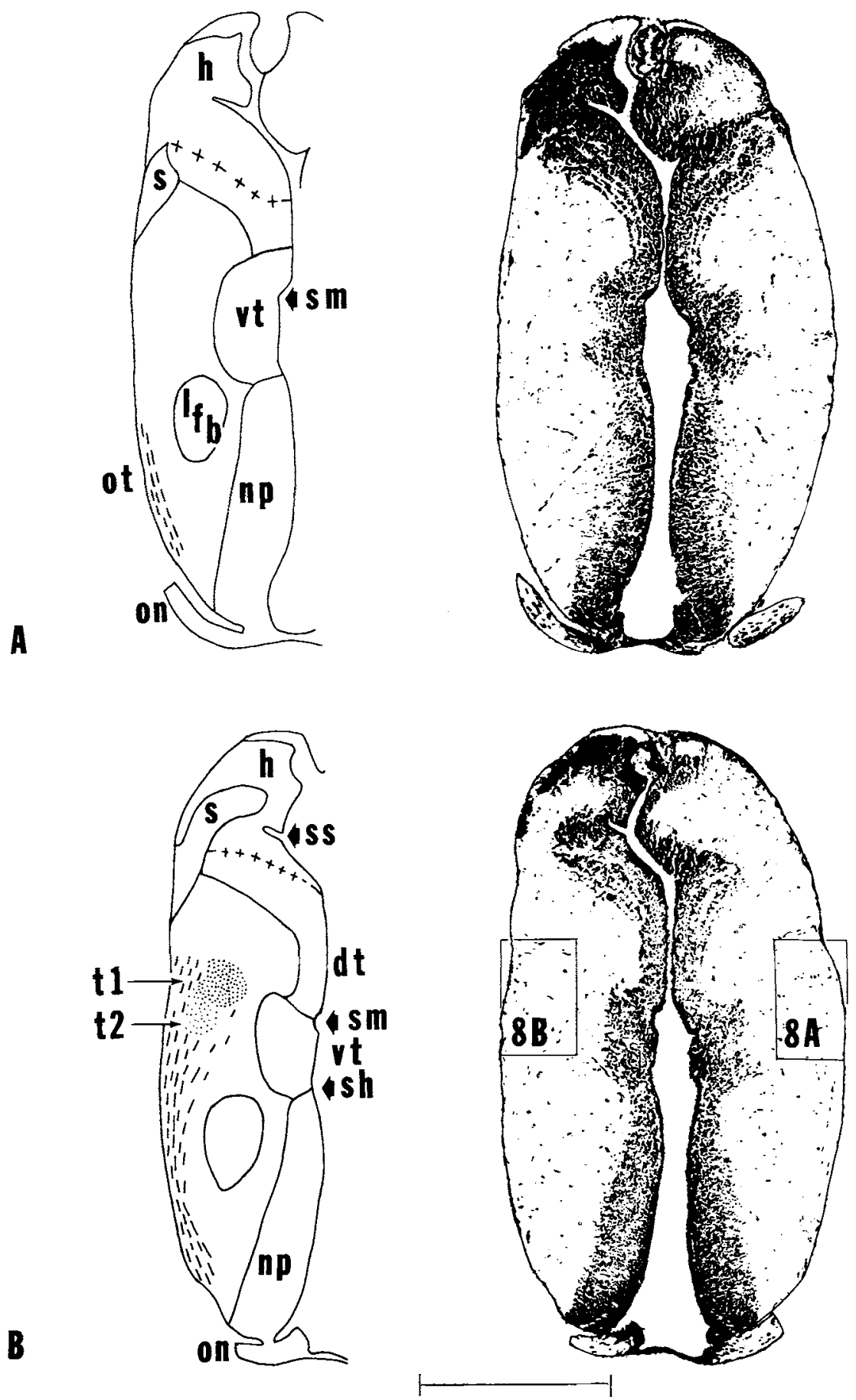

Fig. 2A Transverse section through the diencephalon of Protopterus at the level of the entry of the optic nerves. In this and figures 3 to 7 , a Nissl preparation is shown on the right. To the left is a drawing of the side of the brain contralateral to the operated eye. Retinal fibers of passage are represented by dashed lines and terminal fields by stippling. The chartings are based on that autoradiographic case that survived for three days.

$B$ Transverse section through the level of the rostral thalamus showing the most rostral terminal fields $(t 1,2)$. Bar scale in this figure and in figures 3 to 7 represents $1 \mathrm{~mm}$. Crosses in figures 2 to 4 indicate probable cytological boundaries where there is poor resolution based on normal anatomy. 
'73 for recent reviews) very little attention has been paid to diencephalic and mesencephalic organization. Schnitzlein and Crosby ('68) have published the most extensive description of these brain regions. Their division of the diencephalon into major zones relied heavily on the ventricular sulci, as the lepidosirenid diencephalon, unlike that of most vertebrates, consists of a continuous plate of neurons that lie in a periventricular position with few cell-free breaks that might facilitate recognition of distinct cytological nuclei. These authors utilized three sulci to define the four diencephalic regions recognized by most workers. A subhabenular sulcus, clearly observable in figure 2 , defined the ventral extent of the epithalamus, while a second sulcus, sulcus medius (figs. 2-4), defined the ventral extent of the dorsal thalamus. Finally, a third sulcus, the superior hypothalamic sulcus (figs. 2-3), defined the border of the ventral thalamus and hypothalamus. After recognizing these major diencephalic zones, Schnitzlein and Crosby then described a lateral and medial series of nuclei for each of the major diencephalic zones. This description bears a remarkable similarity to the descriptions of the diencephalon of a number of amphibians (Frontera, '52) and reptiles (Huber and Crosby, '26).

The number and distribution of migrated neurons is so sparse in the dipnoan material I have examined, which includes both larval and adult stages, that I am unable to recognize most of their nuclear groups and, therefore, prefer to recognize only major zones divided into medial periventricular cell plates and lateral regions of neuropil. In several cases it is difficult, if not impossible, to establish criteria based on non-experimental evidence even to recognize boundaries for major diencephalic zones.

While the subhabenular sulcus is clearly recognizable, there appears to be little justification for excluding from the habenula those cells that lie ventral to it (figs. $2 A, B$ ). There is no change in the diameter of the somata and only a gradual change in the packing density of the cells as the cellular plate is traced ventrally. The cells located ventral to the subhabenular sulcus have been termed the subhabenular region by Schnitzlein and Crosby ('68) and assigned to the epithalamus. However, they present no criteria for recognition of this cell group, nor do they define its bound- aries. At present, I cannot recognize a distinct boundary between the epithalamus and dorsal thalamus, only an area of transition between a dorsomedial dense band of cells and a more ventrolateral loosely laminated plate that may represent such a boundary (fig. 2). A subhabenular region could not be identified or defined in my preparations.

I have not utilized the sulcus medius to define the dorsal boundary of the ventral thalamus as did Schnitzlein and Crosby. In most osteichthyans the sulcus medius is located near a laminated plate of neurons that forms a cap around this sulcus (fig. 2A). This plate is usually defined as the ventral thalamus, and the sulcus medius varies in its relationship to the cell plate in the rostro-caudal plane (Nieuwenhuys and Bodenheimer, '66). Rostrally the sulcus is usually located at the mid-point of the cell plate as seen in the transverse plane, while caudally it marks the dorsal border of the cell plate (Northcutt and Butler, '76). I have preferred to rely on changes in the thickness of the periventricular cell plate and its packing density to define major divisions in lungfishes as these criteria can be utilized in actinopterygians and amphibians. In actinopterygians these criteria are also reinforced by distinct cell free breaks in the periventricular cell plate (Northcutt and Butler, '76).

The superior hypothalamic sulcus does coincide with a rostral narrowing of the periventricular cell plate dorsal to the preoptic and dorsal divisions of the hypothalamus and thus provides an additional criterion for defining the dorsal border of the hypothalamus (figs. 2-6). The hypothalamus can be divided into a dorsal division, which extends more rostrally, and a ventral division (fig. 4B). The dorsal hypothalamus extends into the suprachiasmatic ridge and becomes continuous with the caudal, dorsal preoptic nucleus. A distinct boundary could not be established between these two regions of the periventricular plate (fig. 4). A boundary can be distinguished between the dorsal and ventral hypothalamus on the basis of a change in the thickness of the cell plate rostrally (fig. 5) and by a break in the cell plate caudally (fig. 6).

The pretectum was defined differently by Schnitzlein and Crosby ('68) than in this work. They defined that portion of the periventricular cell plate lying lateral to the subcommissural organ (figs. $4 \mathrm{~B}, 5$ ) as the mesencephalic periventricular gray, and the few 

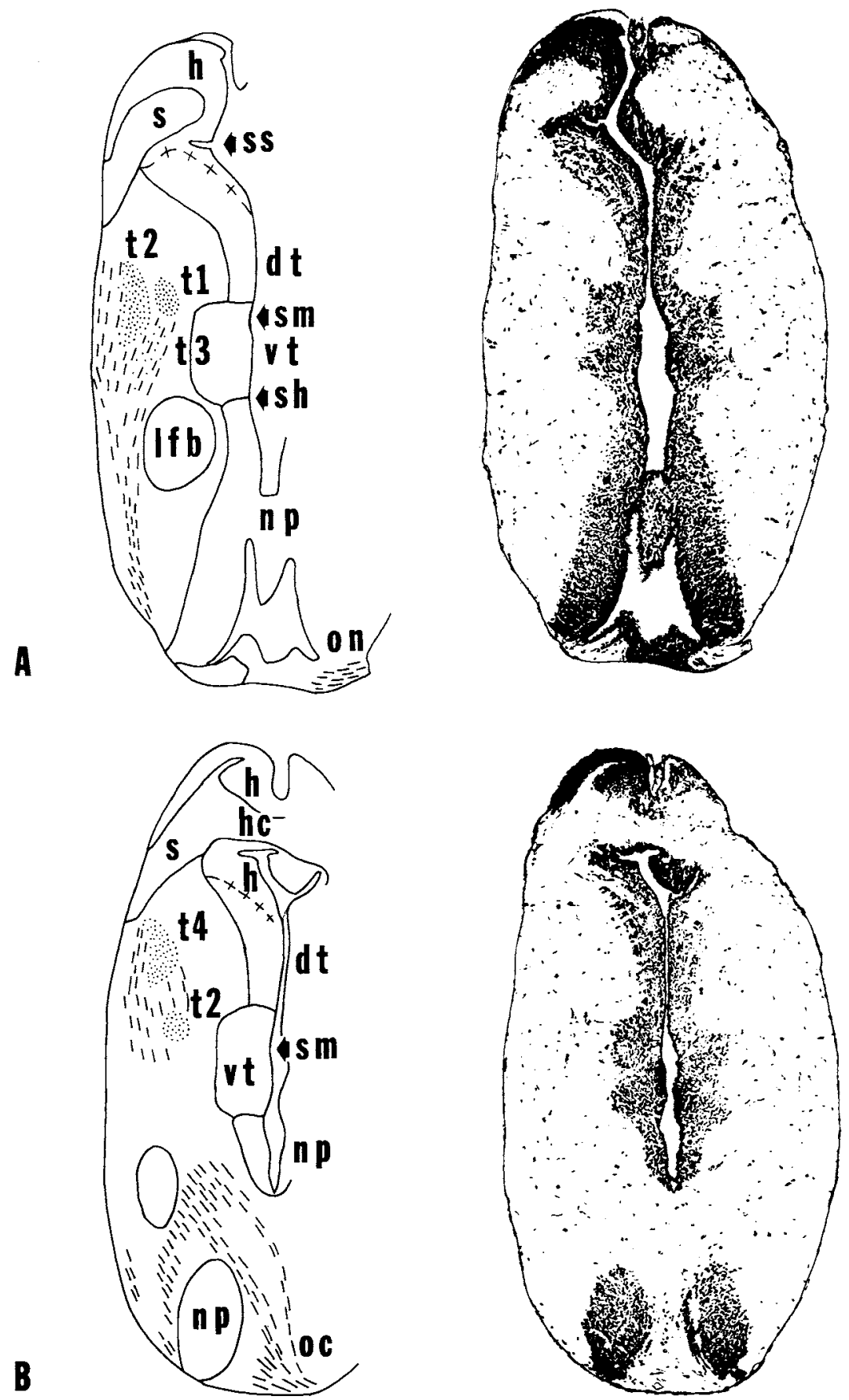

Fig. 3A Transverse section at the level of the dorsal genu of the optic tract.

B Transverse section at the level of the optic chiasm. Note that three of the thalamic retinal targets are actually located rostral to the optic chiasm (figs. 2,3). 
scattered cells of the lateral neuropil at this level as the pretectal area. I believe their mesencephalic periventricular gray should be interpreted as the pretectal region because the topography of this area is identical to that of the pretectum of other vertebrates. The dorsal thalamus of most vertebrates continues caudally passing lateral to the subcommissural organ and frequently is continuous with the tectal gray. In all vertebrates examined to date a variable number of retinorecipient groups can be identified in this region (Ebbesson, '70). The dorsal, caudal border of the thalamus is usually defined by the posterior commissure and the caudal border of the pretectum by the appearance of the tectal commissure. In lepidosirenids the periventricular cell plate, defined as the dorsal thalamus by Schnitzlein and Crosby, turns dorsolaterally as the level of the posterior commissure is reached (fig. 5) and becomes continuous with the rostral pole of the optic tectum. A distinct optic terminal field exists in the lateral neuropil at this level (figs. 5B, 9A) as in other vertebrates. In actinopterygians both a superficial and a deep or medial optic pathway exists to this region of the pretectum (Campbell and Ebbesson, '69; Anders and Hibbard, '74; Northcutt and Butler, '76). In lepidosirenids a few neurons scattered in the lateral neuropil constitute a pretectal visual target (fig. 5B), but the majority of the dendrites that compose this neuropil must have their cell bodies in the periventricular gray as do the dendrites of the optic tectum. For these reasons, I have identified the periventricular cell plate of this region as the pretectal cell plate (fig. 5) with an adjacent pretectal neuropil.

At this level no change is seen in the periventricular cell plate defined as the ventral thalamus, and I have considered it to extend caudally to the level of figure $6 \mathrm{~A}$ where a number of changes occur that I interpret as the beginning of the mesencephalic tegmentum. At this level the ventral part of the periventricular cell plate, defined as ventral thalamus, is rapidly replaced by very large neurons that signal the appearance of the nucleus interstitialis and the medial longitudinal fasciculus, clearly mesencephalic structures. The dorsal half of the ventral thalamus shows no change at the level of figure $6 \mathrm{~A}$ except for a slight reduction in the thickness of the cell plate. This transition is achieved within 75 $150 \mu$ and, at levels illustrated in figure $6 \mathrm{~B}$, is clearly mesencephalic in nature and bears a striking resemblance to the mesencephalic peduncle as defined in Ambystoma by Herrick ('48).

The lepidosirenid optic tectum is surely one of the simplest among living vertebrates (figs. $6,7)$. Few, if any, cells are located beyond the periventricular plate, and the plate itself shows no trace of subdivisions such as those seen even in the poorly developed optic tectum of Ambystoma (fig. 10). On the basis of the extent of the retinofugal projections presented in this work, the neuropil can be divided into an upper, or dorsal, half that receives retinal projections; and an inner, or ventral, half, the connections of which must still be established. Clearly, as in other vertebrates, the ventral neuropil contains afferent and efferent tectal pathways. It also contains the trigeminal mesencephalic nucleus, the cell bodies of which are clearly evident in the caudal half of the optic tectum. The ventral border of the optic tectum can be recognized by a slight constriction of the periventricular cell plate (figs. 6, 7) which coincides with the most ventral extent of the outer visual neuropil.

No distinct basal or tegmental optic nucleus could be identified. A small but distinct basal optic pathway arises at the mid-thal amic level (fig. 3B) and runs caudally to midtegmental levels (figs. 4-7, 9C). Throughout its course a few neurons can be identified near or among the optic fibers, and I believe these cells (as well as more medial tegmental plate cells whose dendrites may extend into the basal pathway) must represent a basal optic nuclear population.

The tegmentum does exhibit one clearly migrated nucleus (fig. 7). This distinct population of neurons, superficial isthmal nucleus, can be seen to lie just beneath the pial surface beginning at a mid-tegmental level. The nucleus grows in size and continues caudally until the level of the cerebellum is reached. Its relationships at this level are problematic. It loses its compact form, and its cells become scattered in close proximity to the cells of the periventricular tegmental plate and the granule cells of the auricle of the cerebellum. I have identified a similar nucleus in the coelacanth, Latimeria, and in this species the cell group is continuous with the granular layer of the auricle. A homologous nucleus has been identified in Neoceratodus and termed the ganglion isthmi (Holmgren and van der Horst, 

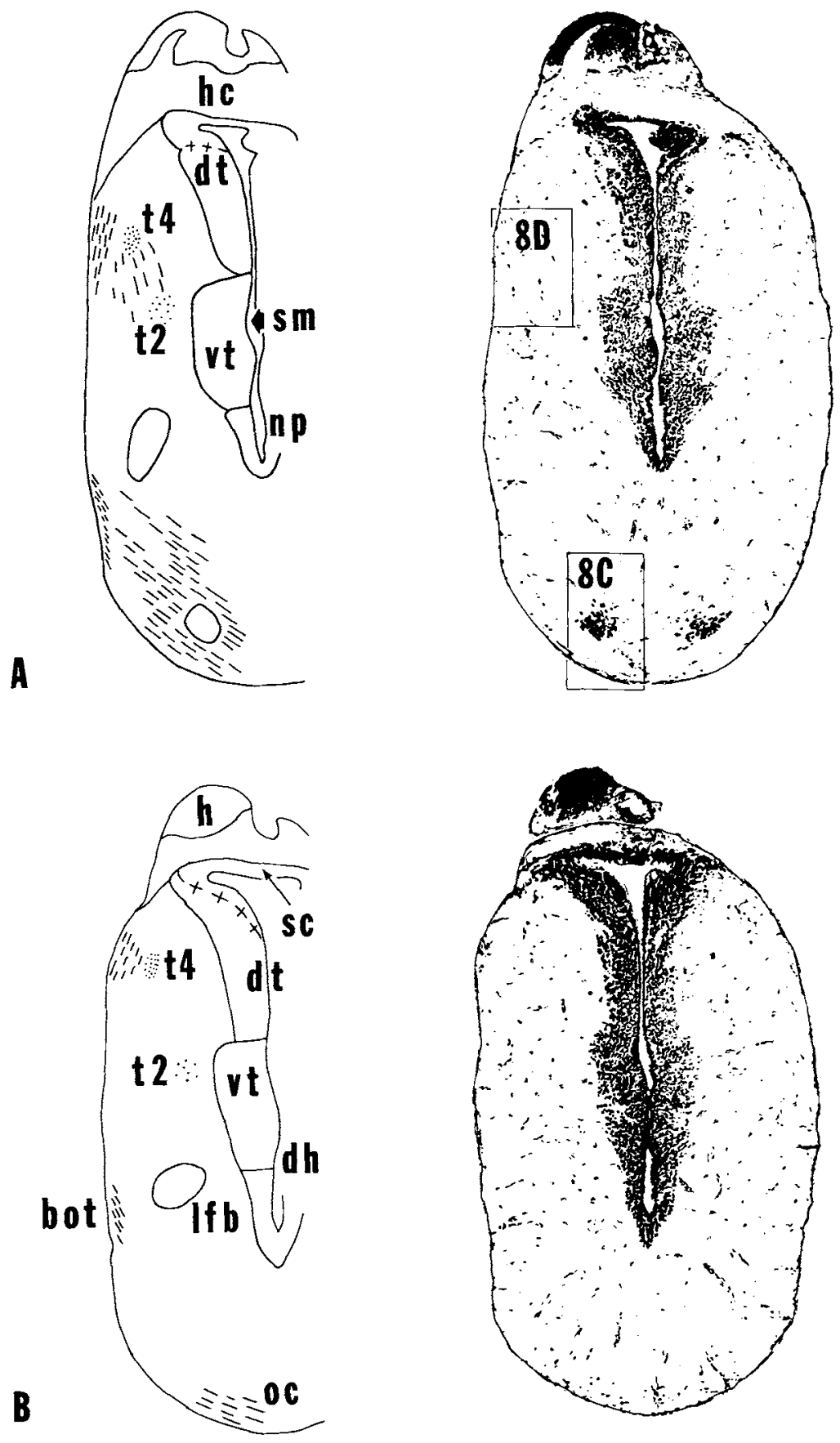

Fig. 4A Transverse section at the level of the caudal border of the preoptic area of the hypothalamus. At this level the basal optic tract can be clearly recognized.

B Transverse section at the level of the caudal thalamus just rostral to the beginning of the pretectum. This is the most caudal extent of the fourth thalamic terminal field ( $t 4$ ). 

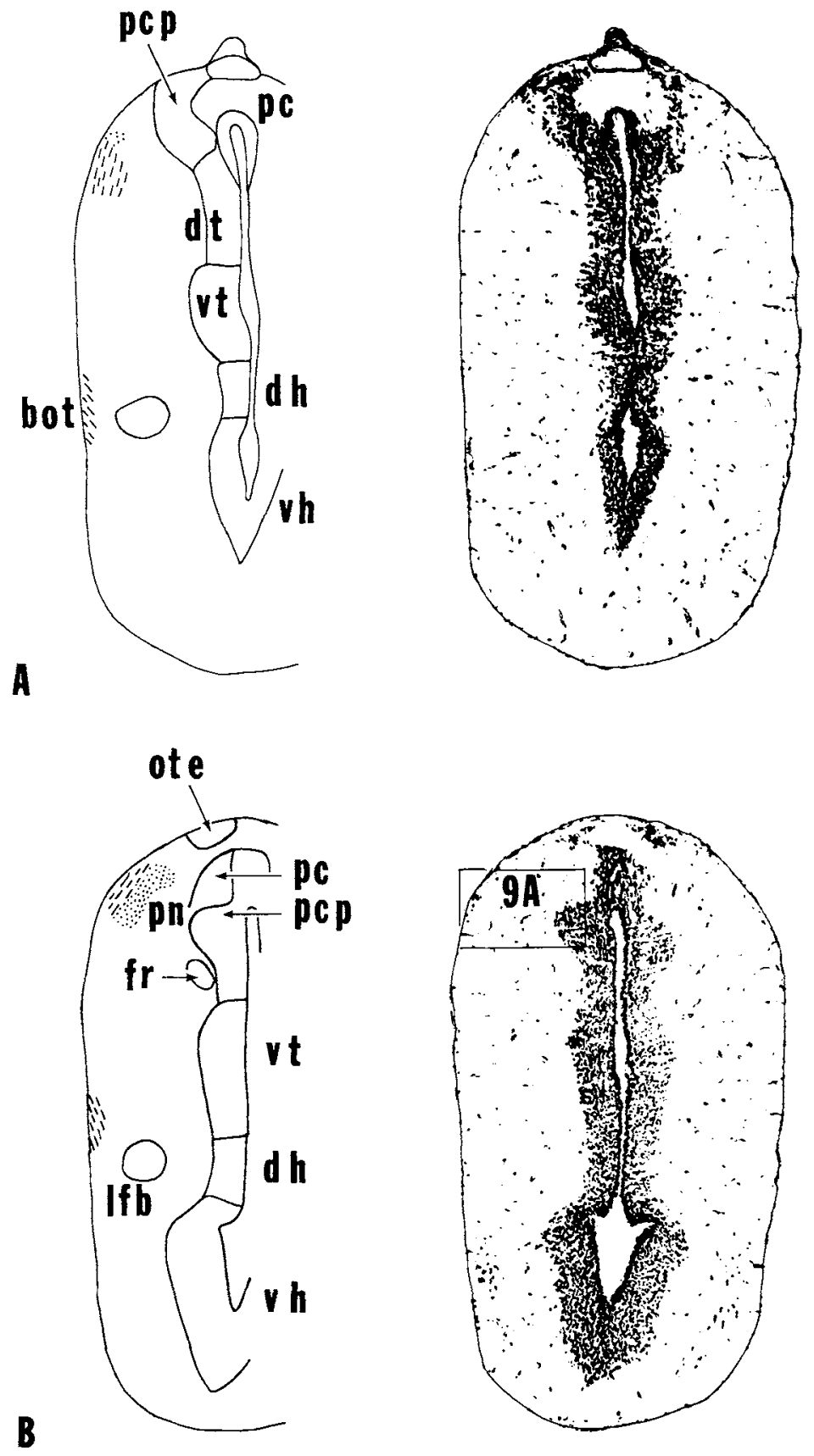

Fig. 5A Transverse section at the level of the rostral pretectum.

B Transverse section at the level of the caudal pretectum showing the beginning of the tectal periventricular cell plate (ote). 

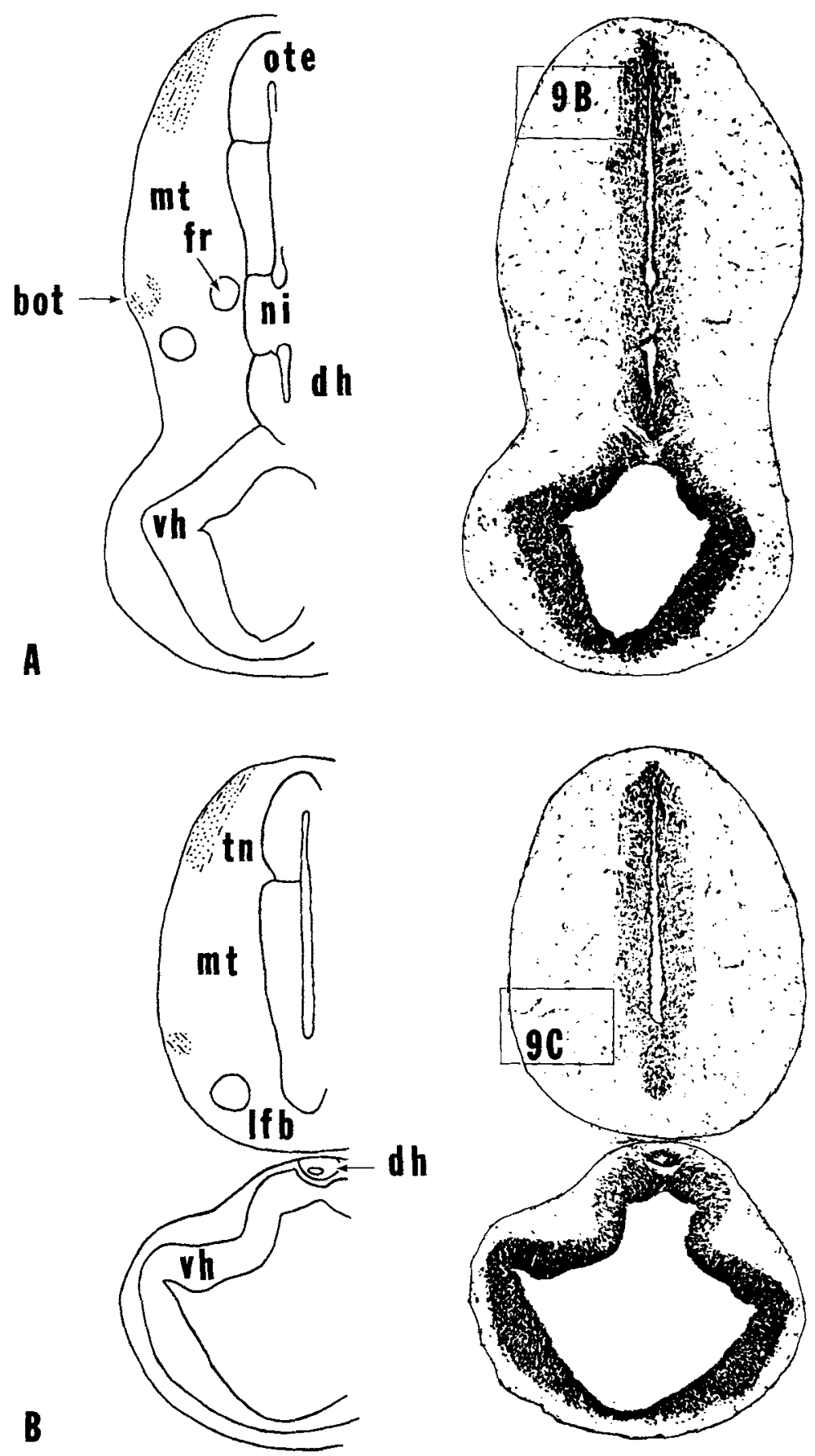

Fig. 6A Transverse section at the level of the rostral optic tectum. The basal optic tract has changed its external configuration and appears as a series of closely packed fasciculi. Terminal fields are probably present at this level.

B Transverse section at a rostral mesencephalic level showing maximal development of the optic tectum. The retinal recipient tectal neuropil extends through the caudal pole of the tectum. 

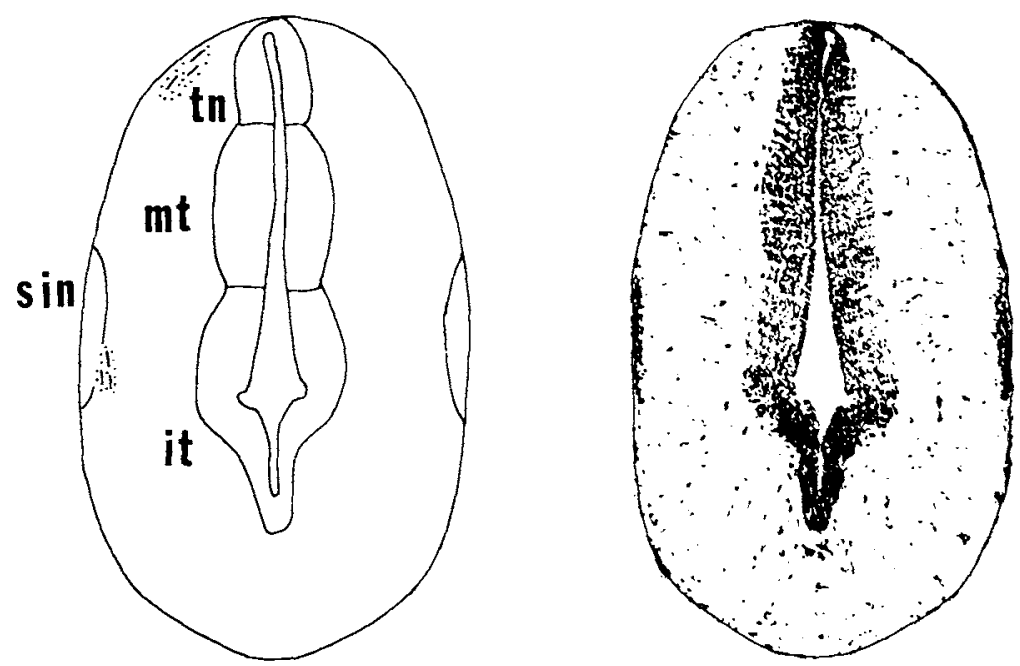

Fig. 7 Transverse section through optic tectum and rostral pole of the superficial isthmal nucleus. This is the most caudal extent of the basal optic tract. Note that the retinofugal terminal field in the tectum does not extend to the dorsal midline at this level nor at preceding tectal levels.

'25) or lateral subcerebellar nucleus (Schnitzlein and Faucette, '69). This nucleus is of particular interest since its rostral pole receives a direct retinal input.

\section{Experimentally determined projections}

The most extensive thalamic retinal targets (figs. 2, 3A) lie rostral to the optic chiasm (figs. 3, 4). Fibers composing the optic nerve enter the optic chiasm at mid-thalamic levels, and decussation is complete. As the optic fibers decussate, they form several fascicles which pass through the caudal pole of the periventricular preoptic nucleus (np). Silver preparations reveal, winding among and over the cell bodies of the periventricular preoptic neurons, numerous club-shaped particles which I have interpreted as preoptic terminals. After passing through the preoptic nucleus, most of the optic fascicles turn rostrally and form a ventral genu of the optic tract. At this point, a basal optic tract (bot) arises and turns caudally as a distinct and separate tract (figs. 3-7) that can be traced throughout the rostral half of the mesencephalon. As the basal optic tract passes caudal to the pretectum, the tract divides into a number of fascicles which gradually decrease in number as they project through the rostral tegmentum.
Occasional cells are scattered along the course of the fascicles and probably receive direct retinal input. Two small fascicles of the basal optic tract were traced into the rostroventral pole of the superficial isthmal nucleus (fig. 7). These fascicles lie on the medial edge of the nucleus and end in apposition to the cell bodies.

At the same level that the basal optic tract separates from the ventral genu of the main optic tract (fig. 3), the main tract turns dorsally, and then rostrally, forming a dorsal

Fig. 8 Photomicrographs of the retinofugal pathways as stained by the Fink-Heimer method after retinal removal (A) or as demonstrated by dark field illumination of autoradiographs after intraocular injection of tritiated proline (B-D).

A Contralateral optic tract degeneration at a rostral thalamic level in Lepidosiren after a 25 day survival time. Orientation and extent of photographed field illustrated in figure $2 \mathrm{~b}$.

B Contralateral optic tract and rostral thalamic terminal fields $(t 1,2)$ in Protopterus. Orientation and extent of photographed field illustrated in figure $2 B$.

$\mathrm{C}$ Optic fibers crossing in chiasm and passing through caudal preoptic area in Protopterus. Cell bodies of preoptic nucleus are bright due to refractile artifact. Orientation and extent of photographed field illustrated in figure $4 \mathrm{~A}$.

D Optic fibers and mid-thalamic terminal fields $(\mathrm{t} 2,4)$ in Protopterus. Orientation also illustrated in figure 4A. Bar scale represents $100 \mu$. 

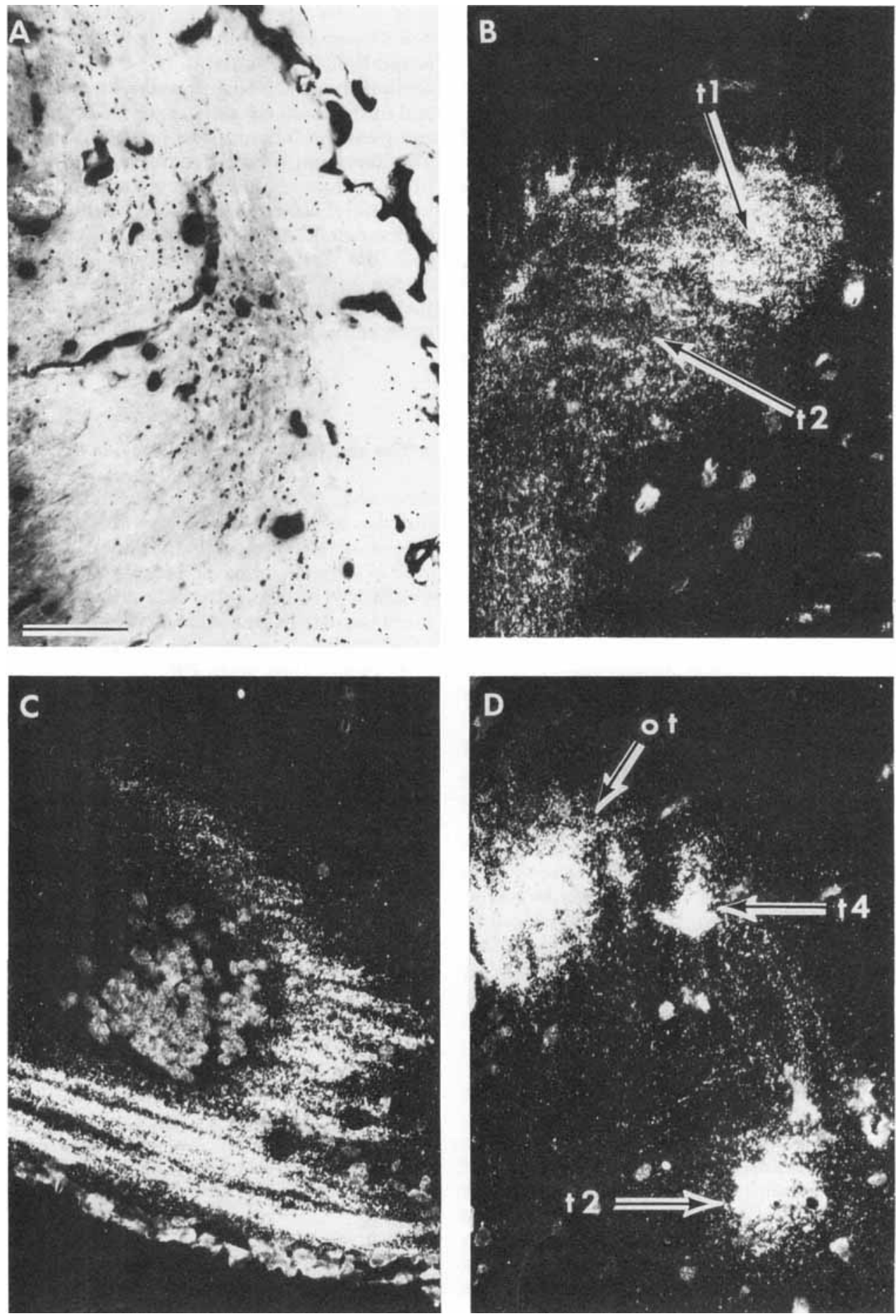

Figure 8 
genu of the optic tract. The dorsal genu gives rise to four distinct terminal neuropil zones within the thalamus.

The first two distinct terminal fields are seen just after the appearance of the dorsal thalamus (figs. 2B, 8B). The most dorsal field (t1) lies just medial to the optic tract and occupies an area of neuropil that could receive the dendrites of both dorsal and ventral thalamic cells. This terminal field rapidly dwindles in size as it is traced caudally where it lies medially very close to the cell bodies of the neurons of the ventral thalamus. In some sections small tongue-like bridges could be followed from the main field to the cell bodies of the ventral thalamus. This first terminal field could not be traced beyond the level of the optic chiasm.

$A$ second terminal field ( $t 2)$ appears just ventral to the first field (figs. $2 \mathrm{~B}, 8 \mathrm{~B}$ ), but rapidly enlarges and replaces the first terminal field (fig. 3A). This is the largest optic target in the rostral thalamus, and, like the first terminal field, it may be in contact with dendrites from both the dorsal and ventral thalamus. This second field ( $t 2)$ also continues ventromedially to lie just lateral to the cell bodies of the ventral thalamus where it ( $t 2)$ can be traced caudally to the rostral border of the pretectum (figs. 4, 8D).

At levels just caudal to the appearance of the first two terminal fields, fibers can be seen leaving the optic tract, streaming medially to enter the ventral border of terminal fields 1 and 2 (figs. 2, 3). I have tentatively identified a third terminal field $(t 3)$ in this region as there are considerable silver grains localized in the lateral ventral thalamic neuropil in addition to the linear silver grains indicative of fibers of passage (fig. 3A). The density of these grains is significantly lower than that of terminal fields 1 and 2; thus this field is not included as part of either of the first two fields.

A fourth terminal field ( $t 4$ ) arises out of the dorsal edge of the second field ( $t 2$ ) just prior to moving to a ventromedial position in the ventral thalamus. The fourth terminal field continues caudally in the dorsal thalamus just medial to the optic tract, and can be traced to the rostral border of the pretectum (figs. 3B, 4, 8D). This field is probably the only thalamic target that contacts only dendrites of dorsal thalamic cells.

As the optic tract passes along the pial sur- face of the pretectum, a new terminal zone can be recognized (figs. 5, 9A). Again the terminal field is confined to the outer half of the pretectal neuropil, and optic fibers probably end on the outer segments of the dendrites of the neurons forming the pretectal cell plate. This terminal zone is continuous with the tectal neuropil and optic fibers, and an associated terminal field can be traced throughout the rostro-caudal extent of the optic tectum (figs. $6,7,9 \mathrm{~B})$. The optic terminals appear confined to the superficial half of the tectal neuropil (tn). No dorso-ventral subdivisions of the tectal terminal field could be recognized.

\section{DISCUSSION}

\section{Phyletic considerations}

The morphological similarities of the diencephalon and mesencephalon of lepidosirenid lungfishes and urodelan amphibians are striking. In both taxa these brain divisions are characterized by periventricular cell plates and extensive zones of lateral neuropil. The similarity in the periventricular plate contours is quite remarkable as indicated by comparable brain sections from Protopterus and Ambystoma (figs. 3, 5, 10).

The primary retinofugal projections in lepidosirenids and urodeles are also similar. To date, the primary retinofugal projections have been experimentally determined in two urodele genera: Cryptobranchus (Riss et al., '63) and Ambystoma (Jakway and Riss, '72; Gruberg, '73). In order to facilitate comparisons between the lepidosirenids and urodeles, I have charted the primary retinofugal projections in Ambystoma (fig. 10) based on six cases of Fink-Heimer stained material in my laboratory. These results agree in most respects with the interpretations of Jakway and Riss (72).

In both lepidosirenids and urodeles, the terminal sites of the primary retinal efferents

Fig. 9 Dark field photomicrographs of autoradiographs following intraocular injection of tritiated proline in Protopterus. Bar scale represents $100 \mu$.

A Contralateral pretectal terminal field. Orienta tion and extent of photographed field illustrated in figure $5 B$.

B Contralateral tectum demonstrating extent of optic fibers and terminal field. Orientation and extent of photographed field illustrated in figure $6 \mathrm{~A}$.

$C$ Contralateral basal optic tract and possible terminal field. Orientation and extent of photographed field iliustrated in figure $6 \mathrm{~B}$. 

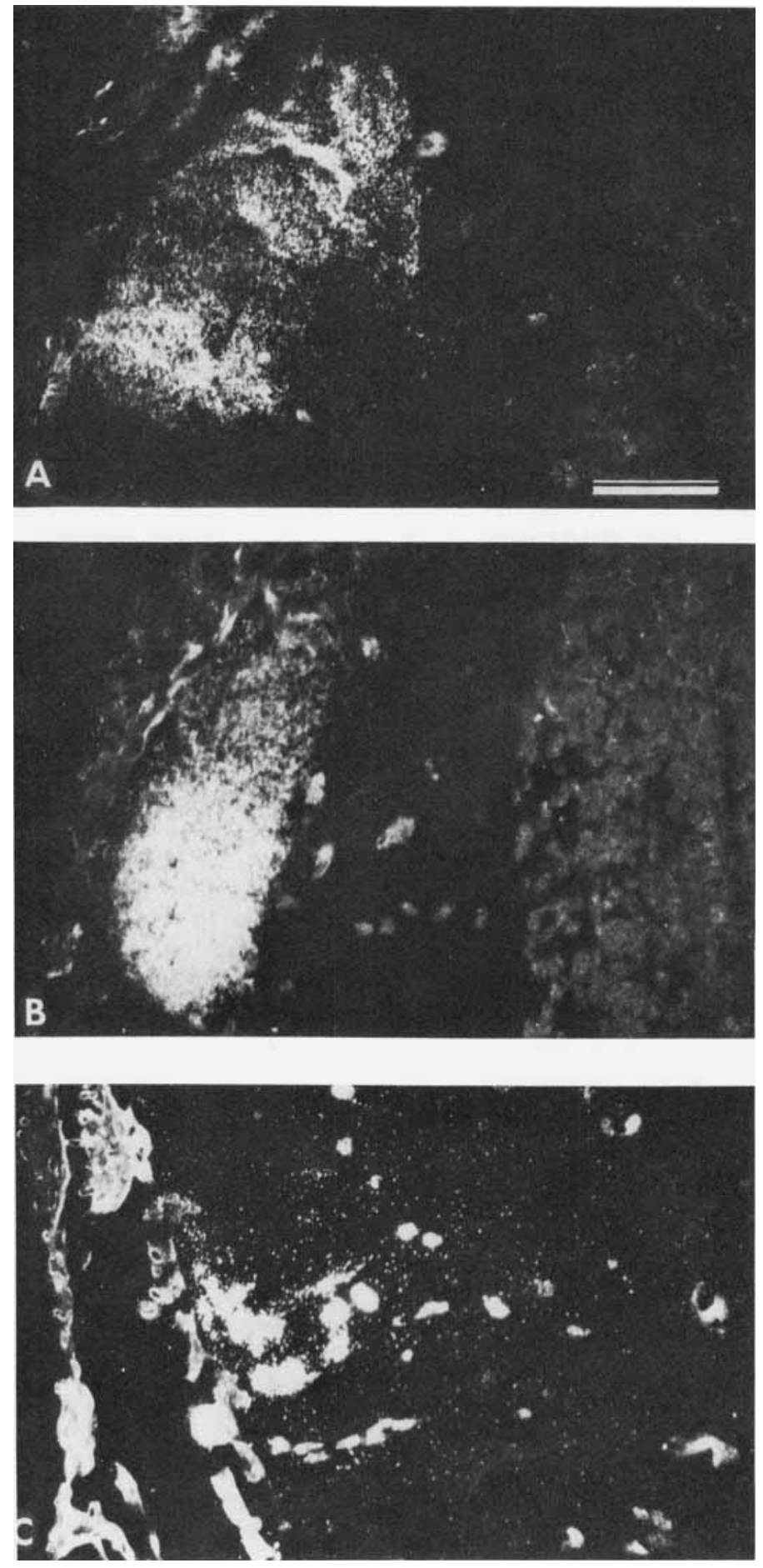

Figure 9 
are restricted to areas of lateral neuopil. The single obvious exception appears to be the preoptic terminal site where optic fibers snake among the cell bodies and arborize on dendrites and cell bodies of the periventricular preoptic nucleus.

The thalamus of both lepidosirenids and urodeles contains a number of discrete retinal targets. Four such thalamic targets can be recognized in both Lepidosiren and Protop. terus. Targets 1 and 2 (figs. 2, 3) are located at the boundary of the dorsal and ventral thalamus and could thus receive dendrites from neurons located in both thalamic areas. Target 3 (fig. 3A) is restricted to the lateral neuropil of the ventral thalamus, and most likely receives only dendrites of ventral thalamic neurons. In contrast, target 4 (figs. $3 B, 4$ ) is situated in the upper half of the neuropil of the dorsal thalamus and probably receives only dendrites of dorsal thalamic neurons. This last target is the only thalamic target where a few neurons are scattered among the retinal terminals of the lateral neuropil. This fourth target was recognized by Schnitzlein and Crosby ('68) and termed the pars dorsalis of the lateral geniculate nucleus. The first three retinal targets recognized in the present study occupy areas of the lateral thalamic neuropil, termed the pars ventralis of the lateral geniculate nucleus, anterior ventral area, and ventrolateral region of the ventral thalamus by Schnitzlein and Crosby.

I agree with Jakway and Riss ('72) that these retinal recipient targets, or fields, should not be labeled with such seductive terms as lateral geniculate body, or nucleus of Bellonci, as has most frequently been the case in describing vertebrate diencephalic regions with extensive periventricular cell plates. This practice is particularly confusing since these targets cannot be characterized by distinct populations of cell bodies, and it is impossible to recognize many of these targets as distinct areas in non-experimental material.

Three distinct retinal thalamic targets were recognized in Ambystoma by Jakway and Riss ('72). These were termed the neuropils of the pars dorsalis and pars ventralis of the thalamus, and the neuropil of Bellonci. Comparison of these fields in Ambystoma (fig. 10) and lepidosirenids is complicated by the differences in the number of targets in these taxa. In Ambystoma the most extensive target, termed the neuropil of Bellonci by Jak way and Riss, lies lateral to the cellular plate marked by the medial sulcus. This same re- gion in lepidosirenids is occupied by targets 1 , 3 , and the rostral half of 2 . In the lepidosirenids only a single target (t2) continues caudally in the central thalamus, and this region in Ambystoma was similarly recognized as the neuropil of the ventral thalamus by Jakway and Riss. These workers also recognized a retino-recipient area, located dorsal to the neuropil of Bellonci, that they termed the neuropil of the dorsal thalamus. A comparable target is recognizable and is labeled as target 4 in lepidosirenids (figs. 3B, 4).

Jakway and Riss ('72) identified retinal projections to the pretectal neuropil, the outer half of the tectal neuropil, and a small area of neuropil termed the ventrolateral area of the peduncle in Ambystoma. These targets correspond closely to the pretectal neuropil, tectal neuropil and basal optic neuropil of lepidosirenids (figs. 5-7).

The basal optic tract of both lepidosirenids and urodeles runs just beneath the pial surface of the tegmentum (figs. 5, 7, 10). In this respect the lepidosirenid condition is identical to that of tetrapods, and is unlike that of actinopterygians which possess a basal optic tract that courses medially to terminate in a neuropil located immediately adjacent to the periventricular cell plate (Campbell and Ebbesson, '69; Northcutt and Butler, '76).

Riss et al. ('63) reported similar retinofugal projections in Crytobranchus; however, the hellbender's optic tracts are completely crossed as in lepidosirenids. Further comparisons with the hellbender are difficult as Riss et al. utilized the original Nauta method (Nauta, '57), and the chartings were not as detailed as those of Ambystoma. Autoradiographic studies of the retinal projections in Cryptobranchus and Necturus, or Amphiuma, would prove particularly informative since these taxa occupy an ecological niche, i.e., an adaptation involving reduced vision, comparable to the lepidosirenids.

The cytoarchitectonics of the diencephalon and mesencephalon, as well as the experimentally determined primary retinofugal projections, are remarkably similar in lepidosirenids and urodeles. This similarity is far greater than that recorded for any other of the major vertebrate categories. Both also lack a deep or medial optic pathway traversing the diencephalon and ending in the deep tectal laminae, a feature which appears to characterize actinopterygians (Northcutt and Butler, '76).

It is tempting to assume that these simi- 

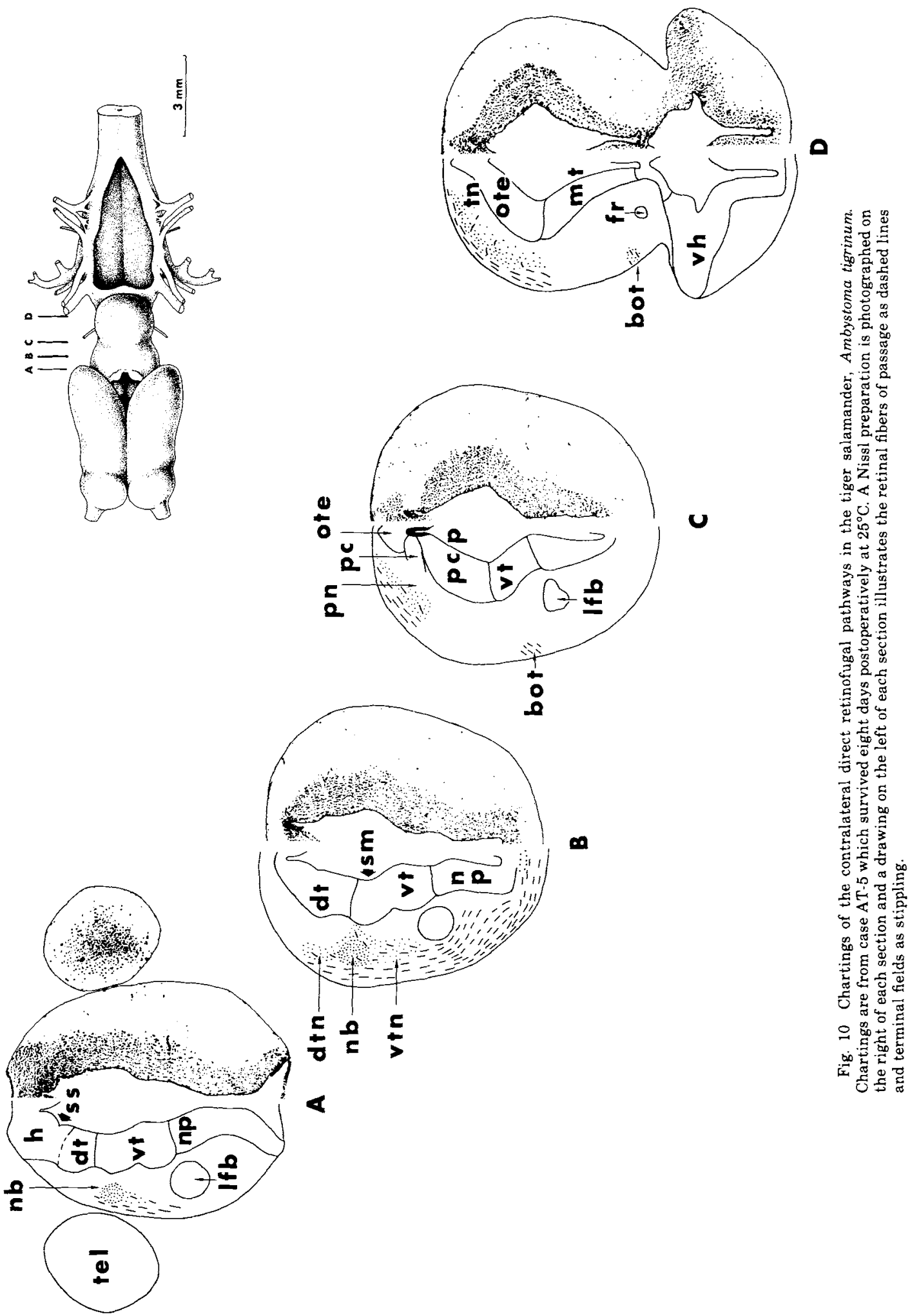
larities are due to close taxonomic affinity between lepidosirenids and urodeles as Romer ('66) suggested. However, these similarities may have been inherited from the common ancestral gnathostome stock, and accentu. ated by parallel neotenic trends in both lepidosirenids and urodeles.

Mayr ('69) has discussed the danger of using regressive characters in the analysis of phyletic relationships: certainly the visual system of lepidosirenids demonstrates such regressions (Ali and Anctil, '73). Neoteny clearly leads to many secondary simplifications in morphological features (De Beer, '58), and the lack of tectal lamination and extensive neuropils are most likely the result of neoteny in both lepidosirenids and urodeles. The absence of a deep optic pathway might also be a result of neoteny. This possibility should be tested by examination of Latimeria and Neoceratodus. Latimeria, the sole living crossopterygian, is a big-eyed, active predator with large optic nerves and a well-laminated optic tectum (Northcutt and Neary, '75). Neoceratodus is considered the most primitive living dipnoan (Moy-Thomas, '71), and is similar in many respects to Latimeria (Nieuwenhuys, '69; Northcutt and Neary, '75). If the visual systems of Latimeria and Neoceratodus are more similar to those of lepidosirenids and amphibians than to those of actinopterygians, this would provide new evidence supporting Romer's hypothesis of osteichthyian relationships.

\section{Evolution of visual pathways}

The 300 -fold range in number of retinal ganglion cells among lepidosirenids, urodeles and frogs allows the testing of several hypotheses regarding the evolution of visual pathways in these taxa. Reduction in the number of retinal ganglion cells might result in the reduction of specific retinal targets, particularly if separate ganglion cell populations form the first link in extensive subcircuits that mediate distinct visual behaviors, as many recent studies suggest (Schneider, '69, '70; Ewert, '70; Ingle, '73). If specific retinal targets are lost, then evidence exists that selection acts at the level of specific retinofugal pathways rather than on the total retinofugal projection. If selection acts at the level of the total retinofugal projection, we might expect that reduction in the total num. ber of retinal ganglion cells would result in reduction in all primary pathways, but would not result in the specific loss of any single retinofugal projection.

It is also likely that an increase in selective pressure(s), resulting in an increase in the number of retinal ganglion cells, would also be mirrored by the addition of "new" retinal targets or by an overall increase in size of the already existing retinal targets.

One further evolutionary insight may be gained by examination of neotenic cases. If loss of distinct retinal targets is associated with failure of the embryonic matrix zone to undergo the migration that produces laminated neural populations, it could be argued that laminated structures in the central nervous system are normally associated with an increase in the number of neurons performing distinctly different functions. However, lamination could also be the result of re-packing a larger number of neurons performing the same function. Do we find the same number of retinal targets in lepidosirenids and urodeles as in anurans which do show considerable neural migration?

The anuran primary retinal efferents have been most thoroughly studied in Rana pipiens (Knapp et al., '65; Scalia et al., '68; Scalia and Gregory, '70; Scalia and Fite, '74) and Rana esculenta (Lázár and Székely, '69; Lázár, '71). The presence or absence of a preoptic terminal field in Rana is still unresolved. Knapp et al. ('65) reported a preoptic slip, but in a subsequent paper Scalia et al. ('68) retracted the claim. However, Vullings and Kers ('73), using both silver impregnation and autoradiographic techniques, described an ipsilateral retino-preoptic tract in Rana temporaria.

To date, all workers have reported two retinal targets in the rostral thalamus of anurans, a dorsally located neuropil of Bellonci and a ventrally located corpus geniculatum thalamicum. While the ranid thalamus is cytologically more complex than that of lepidosirenids or urodeles, both in number of distinct cytological populations and in migrated neurons, these rostral thalamic retinal targets remain largely confined to lateral neuropil areas. These neuropils in anurans occupy a topographical position lateral to the sulcus medius and ventral thalamus, as do the retinal recipient neuropils in lepidosirenids and urodeles (see particularly figs. 4 and 5 of Scalia and Gregory, '70).

Unlike lepidosirenids and urodeles, a third, more dorsal, retinal recipient target has not been reported in the rostral thalamus of 
anurans. At present the literature suggests that ranids, while possessing more than 300 times the number of retinal ganglion cells (Maturana, '59) seen in lepidosirenids, may actually possess fewer distinct rostral thalamic retinal targets. It is possible that this increase in optic fibers is unrelated to the rostral thalamus of anurans, but rather is related to the more caudal pretectal fields and to the tectum, both of which are far more elaborate in frogs and toads. If this conjecture proves true, it would provide considerable support for the idea of selection at the visual subcircuit level.

However, it is also possible that a third retinal target may exist in the rostral thalamus dorsal to the neuropil of Bellonci. While this prospect at first seems unlikely, a comparable case has occurred in reptiles. Most workers have recognized two major retinal recipient targets in the rostral thalamus of reptiles, a pars dorsalis and a pars ventralis of the lateral geniculate nucleus (Armstrong, '50, '51; Ebbesson, '70; Hall and Ebner, '70; Butler and Northcutt, '71; Halpern and Frumin, '73). In 1968, however, Knapp and Kang reported a distinct third rostral thalamic nucleus which receives a direct and massive retinal input, and which is located dorsal to the nucleus usually termed the pars dorsalis of the lateral geniculate nucleus. The occurrence of this third target has subsequently been confirmed utilizing autoradiography in Sphenodon (Northcutt et al., '74), in Carretta (Bass and Northcutt, '75) and in Caiman (Braford and Northcutt, '77). Similarly, at least three rostral retinal recipient targets have been recognized for some time in birds (Karten and Nauta, '68; Repérant, '73).

While the rostral thalamic comparisons among lepidosirenids, urodeles and anurans cannot be analyzed in further detail at present, the ranid pretectum and tectum are clearly more complex in regard to number of retinal targets and in migrated neuronal populations. The pretectum of ranids is characterized by three distinct retinal targets; the posterior thalamic nucleus, the large-celled pretectal nucleus, and the uncinate pretectal nucleus (Scalia and Fite, '74). Only a single retinal pretectal neuropil can be recognized in lepidosirenids and urodeles.

The superficial half of the ranid tectum is characterized by four distinct strata of optic terminals (Scalia et al., '68; Lázár and Székely, '69; Scalia, '73). No stratification of the optic terminals was detected in the tecta of either Lepidosiren or Protopterus. Differences in the density of the retinofugal projections to the tectum of Ambystoma have been reported in all studies to date (Jakway and Riss, '72; Gruberg, '73; fig. 10, present study). Jakway and Riss have reported the most extensive lamination (six layers) restricted to laminae 1 and 2 of Herrick (42). However, they did not report which of these layers might be terminal fields as opposed to axons of passage.

In summary, the visual system of lepidosirenid lungfishes is one of the most reduced visual systems in living vertebrates, as reflected by the small number of optic fibers. However, these taxa possess the same number of thalamic and pretectal retinal targets as does Ambystoma which has at least 30-fold the number of ganglion cells (Gruberg, '73). The only significant difference in the primary retinofugal projections between lepidosirenids and Ambystoma may be the segregation of optic terminals into distinct laminae in the tectum of Ambystoma. If further studies confirm such a segregation this would also support the interpretation of selection at the visual subcircuit level.

While Rana has 300 times the number of ganglion cells, it does not have an equivalently large number of distinct retinal targets in the rostral thalamus; but retinal hypertrophy in Rana is associated with an increase in the number of migrated thalamic neurons. However, the pretectum and tectum of Rana have increased in both the number of distinct retinal targets as well as migrated neurons. This increase in the number of pretectal and tectal targets again suggests that selection is acting at the visual subcircuit level. The increase in migrated neurons in both the diencephalon and mesencephalon is more difficult to interpret. As the number of distinct retinal thalamic targets does not change, the thalamic migrations might represent an increase in the number of post-synaptic units, recruited without change in function as the number of optic fibers increases. The pretectal and tectal migrations may well reflect an increase in functional types of neurons as the number of distinct retinal targets has changed in these areas.

\section{ACKNOWLEDGMENTS}

I am pleased to thank Doctors M. Braford and C. Gans who read the manuscript and provided helpful suggestions; Mr. D. Bay for his 
assistance with the photography; and Mrs. B. Reed for the histological preparations. This project could not have been completed without the frequent advice and assistance of $\mathrm{Mr}$. Daniel Moreno and Mr. Edward Bronokowski of the Cleveland Aquarium. I gladly acknowledge the many hours that these fine aquarists have lavished on me and my fishes. This study was supported by NIH NS11006 and NSF GB40134 Research Grants.

\section{LITERATURE CITED}

Ali, M. A., and M. Anctil 1973 Retina of the South Ameri can lungfish, Lepidosiren paradoxa Fitzinger. Can. J Zool., 51: 969-972.

Anders, J. J., and E. Hibbard 1974 The optic system of the teleost Cichlasoma biocellatum. J. Comp. Neur., 158: 145 . 154.

Armstrong, J. A. 1950 An experimental study of the visual pathways in a reptile (Lacerta vivipara). J. Anat., 84:146 167.

1951 An experimental study of the visual path ways in a snake (Natrix natrix). J. Anat, 85: 275-288.

Bass, A. H., and R. G. Northcutt 1975 Retinal projections in the Atlantic loggerhead sea turtle (Caretta caretta): an autoradiographic study. Anat. Rec., 181: 308 (Abstract).

Bertmar, G. 1968a Phylogeny and evolution in lungfishes. Acta Zool. Stockh., 49: 189-201.

1968b Lungfish phylogeny. Current Problems of Lower Vertebrate Phylogeny. Nobel Symposium 4. T. Orvig, ed. Almqvist and Wiksells, Stockholm, pp. 259. 283.

Braford, M. R., Jr., and R. G. Northcutt (1977, manuscript in preparation) The retinal projections in the South American spectacled caiman, Caiman crocodilus.

Butler, A. B., and R. G. Northcutt 1971 Retinal projections in Iguana iguana and Anolis carolinensis. Brain Res., 26 . $1-13$

Campbell, C. B. G., and S. O. E. Ebbesson 1969 The optic system of a teleost: Holocentrus re-examined. Brain Behav. and Evol., 2: 415-430.

Clairambault, P., and E. Capanna 1973 Suggestions for a revision of the cytoarchitectonics of the telencephalon of Protopterus, Protopterus annectens (Owen). Boll. Zoll., 40: 149-171

De Beer, G. 1958 Embryos and Ancestors. Third ed. Oxford University Press, $197 \mathrm{pp}$.

Ebbesson, S. O. E. 1970 On the organization of central visual pathways in vertebrates. Brain, Behav, and Evol., 3: $178-194$.

Ewert, J. P. 1970 Neural mechanisms of prey-catching and avoidance behavior in the toad (Bufo bufo L.). Brain, Behav. and Evol., 3: 36-56.

Fink, R. P., and L. Heimer 1967 Two methods for selective silver impregnation of degenerating axons and their syn aptic endings in the central nervous system. Brain. Res. 4: $369 \cdot 374$

Frontera, J. G. 1952 A study of the anuran diencephalon J. Comp. Neur., 96: 1-69.

Gruberg, E. R. 1973 Optic fiber projections of the tiger salamander Ambystoma tigrinum. J. Hirnforsh., 14: 399 . 411.

Hall, W. C., and F. F. Ebner 1970 Thalamotelencephalic projections in the turtle (Pseudemys scripta). J. Comp. Neur., 140: 101-122.

Halpern, M., and N. Frumin 1973 Retinal projections in a snake, Thamnophis sirtalis. J. Morph., 141: 359-381.
Herrick, C. J. 1942 Optic and postoptic systems in the brain of Ambystoma tigrinum. J. Comp. Neur., 77: 191353.

1948 The Brain of the Tiger Salamander. The Uni versity of Chicago Press, $409 \mathrm{pp}$.

Holmgren, N., and C. J. van der Horst 1925 Contribution to the morphology of the brain of Ceratodus. Acta Zool., 6: $59-165$.

Huber, G. C., and E. C. Crosby 1926 On thalamic and tectal nuclei and fiber paths in the brain of the American alligator. J. Cornp. Neur., 40:97-227.

ingle, D. 1973 Two visual systems in the frog. Science, 181 : 1053-1055.

Jakway, J. S., and W. Riss 1972 Retinal projections in the tiger salamander, Ambystoma tigrinum. Brain, Behav. and Evol., 5: 401-442.

Jarvik, E. 1967 On the structure of the lower jaw in dipnoans: with a description of an early Devonian dipnoan from Canada, Melanognathus canadensis gen. et sp. nov. Fossil Vertebrates. C. Patterson and P. H. Greenwood, eds. J. Linn. Soc. (zool.), 47: 155-183.

1968 The systematic position of the Dipnoi. Current Problems of Lower Vertebrate Phylogeny. Nobel Symposium 4. T. Orvig, ed. Almqvist and Wiksell, Stockholm, pp. 223-245.

Karten, H., and W. J. H. Nauta 1968 Organization of retinothalamic projections in the pigeon and owl. Anat. Rec., 160: 373 (Abstract).

Knapp, H., and D. S. Kang 1968 The retinal projections of the side-necked turtle (Podocnemis unifilis) with some notes on the possible origin of the pars dorsalis of the lateral geniculate body. Brain, Behav. and Evol., 1: 369 . 404.

Knapp, H., F. Scalia and W. Riss 1965 The optic tracts of Rana pipiens. Acta Neurol. Scand., 41: 325-355.

Kokoros, J. J., and R. G. Northcutt 1977 Telencephalic efferents of the tiger salamander Ambystoma tigrinum tigrinum (Green). J. Comp. Neur., 173: 613-628.

Lázár, Gy. 1971 The projection of the retinal quadrants on the optic centres in the frog. Acta Morph. Acad. Sci. Hung., 19: 325-334.

Lázár, Gy., and G. Székely 1969 Distribution of optic terminals in the different optic centres of the frog. Brain Res., 16: 1-14.

Maturana, H. R. 1959 Number of fibers in the optic nerve and the number of ganglion cells in the retina of anurans. Nature, 183: 1406-1407

Mayr, E. 1969 Principles of Systematic Zoology. McGrawHill, New York, $428 \mathrm{pp}$.

Moy-Thomas, J. A. 1971 Palaeozoic Fishes. Second ed. Revised by T.S. Miles. W. B. Saunders Co., Philadelphia, $259 \mathrm{pp}$.

Nauta, W. J. H. 1957 Silver impregnation of degenerating axons. New Research Techniques of Neuroanatomy. W. F. Windle, ed. Thomas Pub. Co., Springfield, pp. 17-26.

Nieuwenhuys, R. 1969 A survey of the structure of the forebrain in higher bony fishes (Osteichthyes). Ann. N.Y. Acad. Sci., 167: 31-64.

Nieuwenhuys, R., and T. S. Bodenheimer 1966 The diencephalon of the primitive bony fish Polypterus in light of the problem of homology. J. Morph., 118: 415-450.

Nieuwenhuys, R., and M. Hickey 1965 A survey of the forebrain of the Australian lungfish Neoceratodus forsteri. J. Hirnforsch., 7: 433-452.

Northcutt, R. G., M. R. Braford, Jr. and G. E. Landreth 1974 Retinal projections in the tuatara Sphenodon punctatus; an autoradiographic study. Anat. Rec., 178: 428 (Abstract).

Northcutt, R. G., and A. B. Butler 1976 Retinofugal path- 
ways in the longnose gar, Lepisosteus osseus (Linnaeus). J. Comp. Neur., 166: 1-16.

Northcutt, R. G., and T. J. Neary 1975 Observations on the optic tectum of the coelacanth, Latimeria chalumnge. Amer. Zool., 15: 806 (Abstract).

Repérant, J. 1973 Nouvelles données sur les projections visuelles chez le Pigeon (Columba livia). J. Hirnforsch., 14: $151-187$.

Riss, W., and J. S. Jakway 1970 A perspective on the fundamental retinal projections of vertebrates. Brain, Behav. and Evol., 3: 30-35.

Riss, W., H. D. Knapp and F. Scalia 1963 Optic pathways in Cryptobranchus allegheniensis as revealed by the Nauta technique. J. Comp. Neur., 121: 31-43.

Rochon-Duvigneaud, A. 1941 L'oeil de Lepidosiren paradoxa. C. R. Hebd. Séances Acad. Sci., 212: 307-309.

1943 Les yeux et la vision des vertébrés. Masson et Cie, Paris, 719 pp.

Romer, A. S. 1966 Vertebrate Paleontology. Third ed. The University of Chicago Press, Chicago, $468 \mathrm{pp}$.

Scalia, F. 1973 Autoradiographic demonstration of optic nerve fibers in the stratum zonale of the frog's tectum. Brain Res., 58: 484-488.

Scalia, F, and K. Fite 1974 A retinotopic analysis of the central connections of the optic nerve in the frog. J. Comp. Neur., 158: 455-477.

Scalia, F., and K. Gregory 1970 Retinofugal projections in the frog: location of the postsynaptic neurons. Brain, Behav. and Evol, 3: 16-29.

Scalia, F., H. Knapp, M. Halpern and W. Riss 1968 New observations on the retinal projection in the frog. Brain. Behav. and Evol., 1: 324-353.

Schaeffer, B. 1968 Adaptive radiation of the fishes and the fish-amphibian transition. Ann. N. Y. Acad. Sci, 167: 5-17.

Schneider, G. E. 1969 Two visual systems. Science, 163: 897-902.

1970 Mechanisms of functional recovery following lesions of visual cortex or superior colliculus in neonate and adult hamsters. Brain, Behav and Evol., 3:295-323.

Schnitzlein, H. N., and E. C. Crosby 1967 The telencephalon of the lungfish, Protopterus. J. Hirnforsch., 9: 105149

1968 The epithalamus and thalamus of the lungfish, Protopterus. J. Hirnforsch., 10: 351-371.

Schnitzlein, H. N., and J. R. Faucette 1969 General morphology of the fish cerebellum. Neurobiology of Cerebellar Evolution and Development. R. Llinas, ed. AMA Education and Research Foundation, Chicago, pp. 77-106.

Simpson, G. G. 1961 Principles of Animal Taxonomy. Columbia University Press, New York, $247 \mathrm{pp}$

Vullings, H. G. B, and J. Kers 1973 The optic tracts of Rana temporaria and a possible retino-preoptic pathway. Z. Zellforsch., 139: 179-200. 